\title{
Antecedents and Consequences of Service Innovation: An Empirical Study of Touring Business in the Southern Part of Thailand
}

\author{
Walailak Rattanawong \\ Faculty of Management Sciences, Prince of Songkla University Thailand \\ E-mail:kkwalailak@gmail.com \\ Nuttida Suwanno \\ Faculty of Management Sciences, Prince of Songkla University Thailand \\ E-mail: nuttida.n@psu.ac.th
}

Doi:10.5296/jebi.v1i1.5603

URL: http://dx.doi.org/10.5296/jebi.v1i1.5603

\begin{abstract}
The objectives of this study was to investigate the relationships between the antecedents affecting service innovation, namely, entrepreneurial orientation, market orientation, service co-production, information technology adoption, human resource practice, and their relationships with service innovation affecting consequences, which was service performance taking into consideration business environments in selecting strategic factors leading to organizational competitive potential development. The subjects of the study were entrepreneurs and executives of 340 touring businesses in the Southern part of Thailand. The data were collected through structural equation modeling. The results of the study revealed the following. 1) Marketing orientation and human resource practice had positive direct effects on service innovation. 2) Entrepreneurial orientation, service co-production, and information technology adoption had indirect effects on service innovation. 3) Service innovation had positive direct effects on service performance and 4) the goodness of fit of the statistical model fitted well to the evident data.
\end{abstract}

Keywords: Service innovation, touring business, factors

\section{Introduction}

Presently, the service sector plays an important role in development and economic growth at the world level as well as the national level. Business growth in the service sector has a significant impact in terms of economic value and proportion of the labor force (Maglio et al., 


\section{$\Lambda$ Macrothink}

Journal of Entrepreneurship and Business Innovation ISSN 2332-8851

2006). Similarly, tourism in Thailand is considered a large service sector, which is an income source with economic value, and the country's GDP is with a growth rate of more than six percent (Department of Tourism, 2010). Tourism is an important mechanism that creates employments and a variety of occupations scattering throughout the country. However, tourism is an industry with continuous fluctuations and changes in addition to facing with world competition in terms of product and service (Sundbo et al., 2007). Most tourism entrepreneurs in Thailand has not yet been able to adapt to the high market dynamics and fluctuations, especially when Thailand has to be ready to enter the free trade area in 2015. Organizations in the government sector, therefore, provide support for research on service innovation, which is a body of knowledge necessary for development of competence for competitiveness among tourism entrepreneurs (Department of Tourism (2012). Therefore, understanding related factors and important components of service innovation under the tourism context is important for forming strategies to develop service innovation in organizations. This prompted the researcher to conduct this study.

\section{Objectives}

2.1 To investigate the relationships between the antecedents affecting service innovation 2.2 To investigate the relationships between service innovation and service performance

\section{Research Methodology}

\subsection{Population and Subjects}

In this study the unit of analysis is organization. The population of the study consisted of 2,054 touring businesses in three southern provinces of Thailand, which are Phuket, Surat Thani, and Songkhla. The subjects were business owners, entrepreneurs or high-level management of 340 business organizations who are related to service management and know their organizations very well. The data were collected through a questionnaire, one questionnaire for one organization.

\subsection{Research Instrument}

The instrument for data collection of this study was a questionnaire developed by adapting from those developed by various academics. The questionnaire employed Likert scale rating 1 - 5 from Least Practiced (1 mark) to Most Practiced (5 marks) to measure components of antecedents and service innovation. For measuring the consequences, the scale ranged from Least Operated (1 mark) to Most Operated (5 marks). The reliability of the questionnaire was analyzed using Cronbach's Alpha, and the reliability of the entire questionnaire was 0.973. The reliability of each variable is also shown in Table 1.

Table 1. Reliability Coefficients

\begin{tabular}{|l|c|c|c|} 
Variable & Items & Alpha & Adapted from \\
\hline Entrepreneurial Orientation (Eo) & 12 & 0.886 & Nasution et al. (2011) \\
Risk taking (rik) & 4 & 0.776 & Baker \& Sinkula (2009) \\
Proactiveness (pra) & 4 & 0.768 & Li et al. (2008) \\
Innovativeness (int)) & 4 & 0.819 & \\
\hline
\end{tabular}




\begin{tabular}{|c|c|c|c|}
\hline Marketing Orientation (Mo) & 12 & 0.902 & Jaw et al. (2010) \\
\hline Customer orientation (cso) & 4 & 0.823 & Cheng \& Krumwiede (2010) \\
\hline Competitor orientation (cpo) & 4 & 0.848 & Narver \& Slater (1990) \\
\hline Interfunctional coordination (ifc) & 4 & 0.870 & \\
\hline Service Co-production (Cov) & 8 & 0.876 & Chen et al. (2011) \\
\hline Customer cooperative (coc) & 4 & 0.823 & Auh et al. (2007) \\
\hline Partner cooperative (cop) & 4 & 0.848 & \\
\hline Information Technology Adoption (Ita) & 12 & 0.913 & Chen \& Tsou \\
\hline IT infrastructure (inf) & 4 & 0.800 & $(2007)$ \\
\hline Strategic alignment (sra) & 4 & 0.865 & \\
\hline Individual learning (ndl) & 4 & 0.856 & \\
\hline Human Resource Practice (Hr) & 10 & 0.904 & Nasution et al. (2011) \\
\hline Job-related (jor) & 6 & 0.868 & Chen \& Huang (2009) \\
\hline Reward-related (rwr) & 4 & 0.847 & \\
\hline Service innovation $(\mathrm{Si})$ & 10 & 0.917 & Camisón \& Monfort-Mir (2012) \\
\hline Product innovation (pdi) & 5 & 0.877 & Grawe et al. (2008) \\
\hline Process innovation (pci) & 5 & 0.887 & Avlonitis et al. (2001) \\
\hline Service Performance (Pm) & 6 & 0.896 & Chen \& Krumwiede (2010) \\
\hline Market performance (mkp) & 3 & 0.828 & Avlonitis et al. (2001) \\
\hline Financial performance (fap) & 3 & 0.886 & \\
\hline
\end{tabular}

\subsection{Data Collection}

Data were collected from two sources. 1) Data collected from the field-210 copies of the questionnaire were collected from the sites by the researcher. 2) Data collected via the post-200 copies of the questionnaire were mailed to the companies selected from the list available from the Office of Touring Business and Tour Guides Registration, Southern Branch, and 150 copies or 75 percent of the total 200 copies mailed were returned. Thus, the total number of copies of the questionnaire obtained was 360. However, only 340 copies were found to be complete.

\subsection{Data Analysis}

\subsubsection{Basic data}

Basic data analysis was conducted using percentage to describe characteristics of the subjects. The results were that most of the questionnaire respondents or $54 \%$ of them were females, $46.2 \%$ were between $36-54$ years old, and $69.1 \%$ had experience in touring business between $11-20$ years. Most of them or 55.6\% were owners of the business, $55.0 \%$ has been in business between $7-14$ years and had $5-15$ employees in their organizations, and $87.1 \%$ used the Internet in their business to support their service.

\subsubsection{Data testing}

Linear structure relationships between observed variables were tested to determine the distributions of the observed variables used in the development of the model. The test was performed using Pearson product moment correlation coefficients. It was found that the 
variables had linear structure relationships but no pairs of observed variables were found to have a relationship of more than 0.8 . Thus, there was no problem of multi collinearity as shown in Table 2.

Table 2. Pearson product moment correlation coefficients of observed variables

\begin{tabular}{|c|c|c|c|c|c|c|c|c|c|c|c|c|c|c|c|c|c|}
\hline $\begin{array}{l}\text { Observed } \\
\text { variables }\end{array}$ & 1 & 2 & 3 & 4 & 5 & 6 & 7 & 8 & 9 & 10 & 11 & 12 & 13 & 14 & 15 & 16 & 17 \\
\hline 1. rik & 1 & & & & & & & & & & & & & & & & \\
\hline 2. pra & .588 & 1 & & & & & & & & & & & & & & & \\
\hline 3. int & .565 & .616 & 1 & & & & & & & & & & & & & & \\
\hline 4. $\operatorname{cso}$ & .489 & .525 & .541 & 1 & & & & & & & & & & & & & \\
\hline 5. сро & .441 & .520 & .482 & .487 & 1 & & & & & & & & & & & & \\
\hline 6. ifc & .455 & .475 & .491 & .550 & .614 & 1 & & & & & & & & & & & \\
\hline 7. $\operatorname{coc}$ & .410 & .463 & .472 & .509 & .500 & .550 & 1 & & & & & & & & & & \\
\hline 8. cop & .470 & .485 & .481 & .541 & .420 & .454 & .627 & 1 & & & & & & & & & \\
\hline 9. inf & .447 & .409 & .410 & .387 & .477 & .504 & .496 & .421 & 1 & & & & & & & & \\
\hline 10. sra & .441 & .458 & .459 & .385 & .483 & .434 & .542 & .488 & .635 & 1 & & & & & & & \\
\hline 11. ndl & .391 & .433 & .398 & .351 & .415 & .421 & .439 & .450 & .587 & .631 & 1 & & & & & & \\
\hline 12. jor & .433 & .423 & .440 & .436 & .466 & .519 & .546 & .492 & .534 & .599 & .582 & 1 & & & & & \\
\hline 13. rwr & .401 & .375 & .380 & .367 & .460 & .446 & .503 & .395 & .464 & .489 & .469 & .683 & 1 & & & & \\
\hline 14. pdi & .488 & .465 & .467 & .488 & .512 & .534 & .547 & .468 & .507 & .554 & .483 & .614 & .624 & 1 & & & \\
\hline 15. pci & .433 & .449 & .465 & .392 & .479 & .536 & .528 & .459 & .477 & .548 & .520 & .605 & .561 & .687 & 1 & & \\
\hline 16. mkp & .419 & .439 & .449 & .441 & .448 & .487 & .458 & .440 & .467 & .422 & .479 & .574 & .546 & .620 & .608 & 1 & \\
\hline 17. fap & .400 & .360 & .443 & .343 & .452 & .428 & .442 & .398 & .445 & .469 & .422 & .552 & .552 & .584 & 609 & .691 & 1 \\
\hline
\end{tabular}

\subsubsection{Measurement Model}

The measurement model is a model that specifies linear relationships between latent variables. In this study, there were 7 latent variables and 17 observed variables. Goodness-of-fit index of the measurement model was tested and found that the measurement model fitted the empirical data at good levels $(\chi 2=147.592, \mathrm{df}=98, \mathrm{p}=<.001, \mathrm{RMSEA}=0.036, \mathrm{CFI}=0.985$, $\mathrm{SRMR}=0.010$ ). The results of the measurement model estimation revealed that the component weights of every observed variable had a statistical significance of .001 , and the observed variable with the highest standard component weight was job-related (regression weight $=0.864, \mathrm{p}<.001)$ and the prediction value was 0.738 as shown in Table 3 .

Table 3. Measurement data estimates

\begin{tabular}{|l|c|c|c|c|c|c|c|}
\multicolumn{1}{|c|}{ Variables } & $\begin{array}{c}\text { Regression } \\
\text { weights }\end{array}$ & Estimates & S.E. & t & R2 & CR & AVE \\
\hline Entrepreneurial Orientation & & & & & & 0.745 & 0.501 \\
$\quad$ Risk taking & $0.735 * * *$ & 0.904 & 0.067 & 13.498 & 0.541 & \\
$\quad$ Innovativeness & $0.780 * * *$ & 1.033 & 0.072 & 14.371 & 0.609 & \\
Proactiveness & $0.789 * * *$ & 1.000 & - & - & 0.623 & \\
\hline Marketing Orientation & & & & & & 0.750 & 0.500 \\
$\quad$ Customer orientation & $0.718 * * *$ & 0.765 & 0.058 & 13.200 & 0.516 & &
\end{tabular}




\begin{tabular}{|c|c|c|c|c|c|c|c|}
\hline Competitor orientation & $0.739 * * *$ & 0.912 & 0.067 & 13.627 & 0.547 & & \\
\hline Interfunctional coordination & $0.776 * * *$ & 1.000 & - & - & 0.603 & & \\
\hline Service Co-production & & & & & & 0.680 & 0.503 \\
\hline Customer cooperative & $0.827 * * *$ & 1.021 & 0.072 & 14.092 & 0.684 & & \\
\hline Partner cooperative & $0.758 * * *$ & 1.000 & - & - & 0.575 & & \\
\hline Information Technology Adoption & & & & & & 0.751 & 0.500 \\
\hline IT infrastructure & $0.765 * * *$ & 0.938 & 0.067 & 13.928 & 0.586 & & \\
\hline Strategic alignment & $0.829 * * *$ & 1.100 & 0.073 & 15.076 & 0.687 & & \\
\hline Individual learning & $0.764 * * *$ & 1.000 & - & - & 0.583 & & \\
\hline Human Resource Practice & & & & & & 0.664 & 0.501 \\
\hline Job-related & $0.864 * * *$ & 0.993 & 0.060 & 16.523 & 0.738 & & \\
\hline Reward-related & $0.791 * * *$ & 1.000 & - & - & 0.625 & & \\
\hline Service innovation & & & & & & 0.668 & 0.502 \\
\hline Product innovation & $0.840 * * *$ & 0.905 & 0.052 & 17.489 & 0.705 & & \\
\hline Process innovation & $0.818 * * *$ & 1.000 & - & - & 0.670 & & \\
\hline \multicolumn{8}{|l|}{ Performance } \\
\hline Market performance & $0.847 * * *$ & 0.876 & 0.054 & 16.220 & 0.717 & 0.679 & 0.503 \\
\hline Financial performance & $0.815 * * *$ & 1.000 & - & - & 0.665 & & \\
\hline
\end{tabular}

$* * * \mathrm{p}<.001$

\section{Literature Review}

\subsection{Service innovation and Service performance}

It is accepted among academics that service innovation leads to new services and indicates effective development of new services, processes, activities, or improvement of organizational management (Drejer, 2004; Mattsson et al., 2005). At present, it is found that tourism business has to face with a high level of competition; therefore, companies must attach importance to integration of limited resources in order to utilize them effectively to make profits and maintain organizational survival (Roberts \& Amit, 2003). Presenting new service products and a new service process or service innovation to respond to customers' value and needs can help improve the organizational image and lead to sustainable success in business operations. While the overall achievement of an organization is usually assessed by its business performance, many studies found that innovations in the service sector and service innovation have direct influence on business service performance. Therefore, service innovation can be compared to an instrument to meet the needs of the organization which can bring competitive advantages and directly affect organizational performance.

\subsection{Factors affecting service innovation}

\subsubsection{Entrepreneurial Orientation}

Entrepreneurial orientation is to give importance to entrepreneurial personality and characteristics, and is an important mechanism for management that reflects organizational competence. According to Miller (1983), entrepreneurial-oriented organizations should have three components of operation, namely, risk taking, proactiveness, and innovativeness. These 
components can support operations in risk taking even though the goal might not be achieved. Operations that are superior than competitors, and promotion of creativities can lead to new products or services. Entrepreneurial orientation is, therefore, an important factor in creating or pushing service innovation for the organization.

\subsubsection{Marketing Orientation}

Marketing orientation is the most efficient and most effective organizational culture for building personnel behavior, which leads to adding value for customers. Narver \& Slater (1990) state that key components of marketing orientation are made up of customer orientation, competitor orientation, and inter-functional coordination. These components can make a process that creates inter-organizational activities related to data that meet customer satisfaction, and data for analyzing competitors' operations, and related to the importance to steps in coordination of cooperation among employees of the organization. The operations can be beneficial to strategies that are in line with the organizational goal. Thus, marketing orientation is a factor used as supporting data for decision-making in order to make a difference in competition, and eventually lead to service innovation of the organization.

\subsubsection{Service Co-production}

Service co-production is to give importance to those from outside of the organization who participated in designing the service system. These can be performed by many customers and clients in tourism businesses such as transportation, accommodation, restaurants or touring business. These businesses are all basic resources of creativities for information useful for development of new types of service. Service co-production has influence on levels of customer satisfaction, and adds value to the products (Vargo \& Lusch, 2004). In service delivery, the important component of service co-production is cooperation from customers and clients. Thus, service co-production is a business strategy created for that particular organization and it is difficult to imitate. Therefore, the challenge depends on the ability of the organization in managing conflict with customers.

\subsubsection{Information Technology Adoption}

Information technology adoption is information technology management by an organization that leads personnel to decide, change, perceive, and adopt it for its service improvement process. Scott (1991) focuses on importance of information innovation under technological pressure from external environments that force an organization to adopt it and adapt to it. The organization can do this by attaching importance to IT infrastructure, strategic alignment, organizational structure, and individual learning. Information technology adoption is, therefore, a factor that the new generation of management should take into consideration because it can help reduce steps in service and business operations to better respond to customers' needs.

\subsubsection{Human Resource Practice}

Human resource practice is the operation of activities that an organization holds for personnel in order to develop work that can fulfill the organizational goals. Quality of personnel is important for business opportunity and growth, especially service business because the nature 
of service is that it is abstract. Hence, to achieve service innovation development depends on employees' attitudes and skills (Chang et al., 2011). It is important for activities organized for employees to be job-related. These activities include training on job skills development, preparation of facilities for work, search for participating potential, promotion of understanding of career advancement, etc. These activities can create job satisfaction that is reward-related (Nasution et al., 2011), thus, rewards or returns are important for work motivation. It can be said that development of service innovation in an organization cannot be complete without importance given to human resource practice because employees in an organization are important cogs that drive the entire process of practice.

\subsection{Relationships between Variables}

In this study, literature related to service innovation and innovations in the business sector was reviewed in order to find out relationships of variables with direct and indirect influence on service innovation as illustrated in Table 4.

Table 4 Factors influencing service innovation

\begin{tabular}{|l|l|}
\hline \multicolumn{1}{|c|}{ Variables } & \multicolumn{1}{c|}{ Literature reviewed } \\
Entrepreneurial & $\begin{array}{l}\text { Baker \& Sinkula (2009); Maatoofi \& Tajeddini (2011); } \\
\text { Marino } \text { et al.; Nasution } \text { et al. } \text { (2010); }\end{array}$ \\
\hline Marketing Orientation & $\begin{array}{l}\text { AL-Dmour \& Basheer (2012); Agarwal } \text { et al. } \text { (2003); } \\
\text { Cheng \& Krumwiede (2010); Jaw } \text { et al. } \text { (2010); } \\
\text { Mavondo } \text { et al. (2004) } \\
\text { Service Co-production } \\
\text { Chen et al. (2011); Cheung \&To (2011); } \\
\text { Hongqi \& Ruoyu (2012); Ordanini \& Pasini (2008) }\end{array}$ \\
\hline Human Resource Practice & $\begin{array}{l}\text { Chen \& Tous (2007); Ismail \& Mamat (2012); Lee \& Xia (2006) } \\
\text { Chang et al. (2009); Mavondo } \text { et al. (2004); } \\
\text { Nasution } \text { et al. } \text { (2010) }\end{array}$ \\
\hline Service Performance & $\begin{array}{l}\text { Aas \& Pedersen (2010); Cheng \& Krumwiede (2010); } \\
\text { Grawe } \text { et al. } \text { (2009); Thakur \& Hale (2012) }\end{array}$ \\
\hline
\end{tabular}

\section{Research Results}

The results of the study on the relationships between the structural equation modeling of the antecedents and the consequences of the service innovation of the touring business in the Southern part of Thailand had direct effects (DE), indirect effects (IE), and the total effects (TE) on service innovation as shown in Table 5. The results of goodness of fit test of the model to the empirical data are shown in the table below:

Table 5 Coefficients of Direct effects (DE), Indirect effects (IE), and Total effects (TE)

\begin{tabular}{|c|c|c|c|c|c|c|c|c|c|c|c|c|}
\hline \multirow{3}{*}{$\begin{array}{l}\text { Casual } \\
\text { Factors }\end{array}$} & \multicolumn{12}{|c|}{ Cause Factors } \\
\hline & \multicolumn{3}{|c|}{$\mathrm{Hr}$} & \multicolumn{3}{|c|}{ Mo } & \multicolumn{3}{|c|}{$\mathrm{Si}$} & \multicolumn{3}{|c|}{$\mathrm{Pm}$} \\
\hline & $\mathrm{DE}$ & IE & $\mathrm{TE}$ & $\mathrm{DE}$ & IE & $\mathrm{TE}$ & $\mathrm{DE}$ & IE & TE & $\mathrm{DE}$ & IE & $\mathrm{TE}$ \\
\hline Eo & - & - & - & $0.499 * * *$ & - & $0.499 * * *$ & - & $0.198 * * *$ & $0.198 * * *$ & - & - & - \\
\hline Mo & $0.283^{* * *} *$ & - & $0.283 * * *$ & - & - & - & $0.334 * * *$ & - & $0.334 * * *$ & - & - & - \\
\hline
\end{tabular}




\begin{tabular}{|c|c|c|c|c|c|c|c|c|c|c|c|c|}
\hline Cov & - & - & - & $0.478^{* * *}$ & - & $0.478^{* * *}$ & - & $0.211^{* * *}$ & $0.211^{* * *}$ & - & - & - \\
$\mathrm{Ita}$ & $0.619^{* * *}$ & - & $0.619 * * *$ & - & - & - & - & $0.219 * * *$ & $0.219^{* * *}$ & - & - & - \\
\hline $\mathrm{Hr}$ & - & - & - & - & - & - & $0.648^{* * *}$ & - & $0.648^{* * *}$ & - & - & - \\
\hline $\mathrm{Si}$ & - & - & - & - & - & - & - & - & - & $0.886^{* * *}$ & - & $0.886 * * *$ \\
\hline $\mathrm{R}^{2}$ & \multicolumn{3}{|c|}{0.715} & \multicolumn{3}{|c|}{0.836} & \multicolumn{3}{|c|}{0.847} \\
\hline
\end{tabular}

$* * * \mathrm{p}<.001$

5.1 The results of the study on the relationships between causal factors on service innovation of touring business in the Southern part of Thailand were as follows.

5.1.1 Entrepreneurial orientation (Eo) had indirect effects on service innovation through marketing orientation $(\beta 0.198, \mathrm{p}<.001)$.

5.1.2 Marketing orientation (Mo) had positive direct effects on service innovation ( $\beta 0.334$, $\mathrm{p}<.001)$.

5.1.3 Co-production orientation (Cov) had indirect effects on service innovation through marketing orientation $(\beta 0.211, \mathrm{p}<.001)$.

5.1.4 Information technology adoption (Ita) had indirect effects on service innovation through human resource practice $(\beta 0.219, \mathrm{p}<.001)$.

5.1.5 Human resource practice $(\mathrm{Hr})$ had positive direct effects on service innovation $(\beta 0.648$, $\mathrm{p}<.001)$.

5.2 The results of the relationship of service innovation of the touring business in the Southern part of Thailand. It was found that service innovation had positive effects on service performance $(\beta 0.886, \mathrm{p}<.001)$.

5.3 The outputs of the causal and effect model analysis and the effects of service innovation revealed that the model fitted well to the empirical data at a good level. The chi-square statistics was 155.412 at the degrees of freedom of 109, the goodness of fit index was at 0.949, and the root mean square residual was at 0.035 as shown in the figure 1 below.

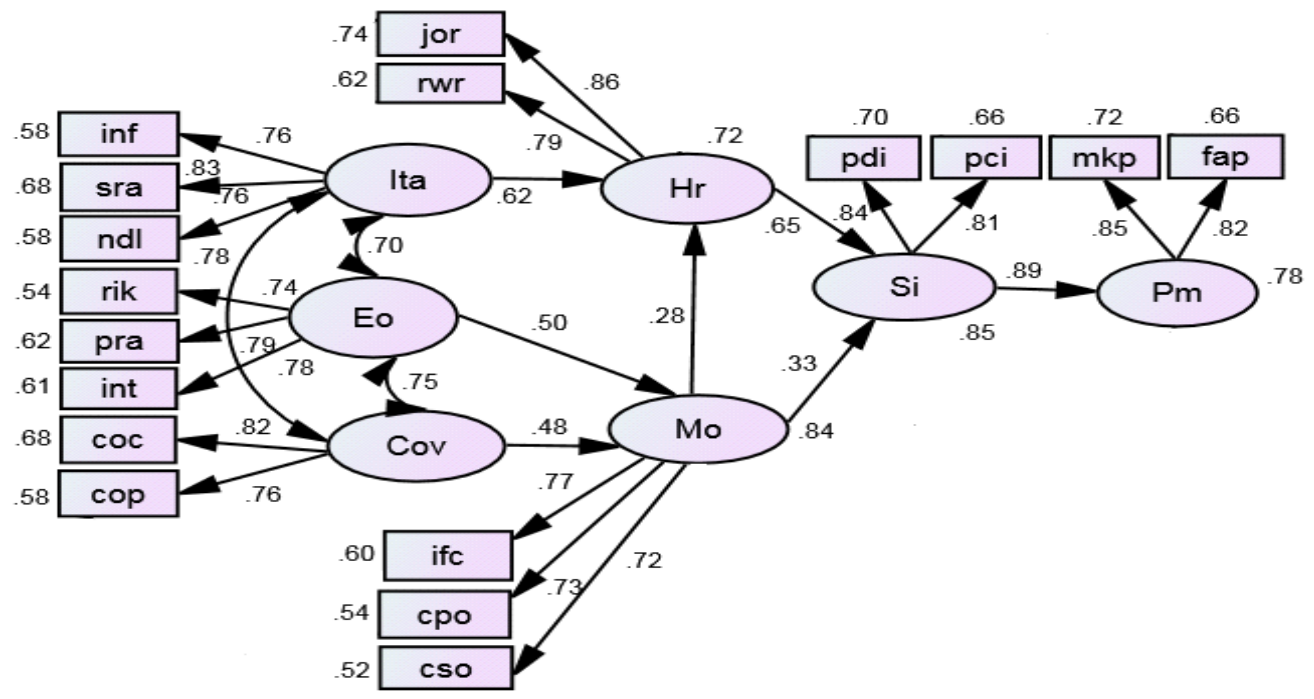

Chi-Square $=155.412, \mathrm{df}=109, \mathrm{p}$-value $=0.002, \mathrm{RMSEA}=0.035, \mathrm{GFI}=0.949$

Figure 1. Path coefficient output of SEM analysis 
5.4 The result of this study apparently reveal that the strategy of service innovation lead to a success in service performance. According to a several studies, it is suggested that service innovation affects positively to service performance (Chan et al., 2009; Den Hertog et al., 2010; Eisingerich et al., 2009) and consequently contribute to competitive advantage (Gebauer et al., 2011). While, the results of relationship among strategic factors proved that entrepreneur orientation is considered as a significant factors in leading activities of other related factors and contribute to the improvement of service innovation within the organization. (Li, 2008; Tajeddine, 2010)

\section{Conclusion}

The problems under the tourism context of Thailand prompted the researcher to conduct this study. Reviewing related literature was performed to identify factors influencing service innovation to be used in the study to find out the relationships between causal factors and the effects on service innovation. The results of the study are as follows:

6.1 The factors that had direct effects on service innovation were marketing orientation and human resource practice, which had the highest influence. It can be seen that human resource is the factor that plays a very important role in service innovation.

6.2 The factors that had indirect effects were entrepreneurial orientation, co-production orientation, and information technology adoption. These factors are important for development of service innovation even though support from other factors is needed.

6.3 The model fitted well to the empirical data at a good level, which indicated that the concepts obtained from the literature reviews fitted well to the empirical data at a good level, too.

\section{Recommendations}

The study on Antecedents and Consequences of Service Innovation: An Empirical Study of Touring Business in the Southern Part of Thailand contributes to development of the body of knowledge necessary for competency development among entrepreneurs in the tourism industry. It can help them see the importance of factors influencing service improvement. For related individuals in the government sector, they can use the study results in developing and forming guidelines for promotion of potential in creating service innovations in tourism organizations.

\section{Acknowledgments}

The author would like to thank the Graduate School, Prince of Songkla University, Thailand for the support given to this research.

\section{References}

Aas, T. H. \& Pedersen, P. E. (2010). The Firm-level effects of service innovation: A literature review. International Journal of Innovation Management, 14(5), 759-794.

AL- Dmour, H. H. \& Basheer, E. (2012). The effect of market orientation on service innovation: 


\section{Macrothink}

Journal of Entrepreneurship and Business Innovation ISSN 2332-8851 2014, Vol. 1, No. 1

A study on the information and communication technology sector in Jordan. International Journal of Humanities and Social Science, 2(19), 222-253.

Agarwal, S., Erramilli, M. K. \& Dev, C. S. (2003). Market orientation and performance in service firms: role of innovation. Journal of Service Marketing, 17(1), 68-82.

Auh, S., Bell, S. J., McLeod, C. S. \& Shih, E. (2007). Co-production and customer loyalty in financial services. Journal of Retailing, 83(3), 359-370.

Avlonitis, G. J., Papastathopoulou, P. G. \& Gounaris, S. P. (2001). An Empirically-Based typology of product innovativeness for new financial services: Success and failure scenarios. The Journal of Product Innovation Management, 18, 324-342.

Baker, W. E. \& Sinkula, J. M. (2009). The complementary effects of market orientation and entrepreneurial orientation on profitability in small businesses. Journal of Small Business Management, 47(4), 443-464.

Camisón, C. \& Monfort-Mir, V. M. (2012). Measuring innovation in tourism from the Schumpeterian and the dynamic-capabilities perspectives. Tourism Management, 33, 776-789.

Chen, C. J. \& Huang, J. W. (2009). Strategic human resource practice and innovation performance - The Mediating role of knowledge management capacity. Journal of Business Research, 62, 104-114.

Chen, J. S. \& Tsou, H. T. (2007). Information technology adoption for service innovation practices and competitive advantage: The case of financial firms. IR Information Research, $12(3), 1-25$.

Chen, J. S., Tsou, H. T. \& Huang, A. Y. H. (2009). Service delivery innovation: Antecedents and impact on firm performance. Journal of Services Research, 12(1), 36-55.

Chen, J. S., Tsou, H.T. \& Russell K. H. (2011). Co-production and its effects on service innovation. Industrial Marketing Management, 40, 1331-1346.

Cheng, C. C. \& Krumwiede, D. (2010). The effects of market orientation and service innovation on service industry performance: An empirical study. Operation Management Research, 3, 161-171.

Cheung, Millissa F. Y. \& To, W. M. (2011). Customer involvement and perception: The moderating role of customer co-production. Journal of Retailing and Consumer Service, 18, 271-277.

Chang, S., Gong, Y. \& Shum, C. (2011). Promoting innovation in hospitality companies through human resource management practices. International Journal of Hospitality Management, 30, 812-818.

Den Hertog, P. (2000). Knowledge-intensive business services as co-producers of innovation. International Journal of Innovation Management, 4(4), 491-528.

Department of Tourism (2010). Summary of the Foreign Tourists 2005-2010, 7. 


\section{I Macrothink}

Journal of Entrepreneurship and Business Innovation ISSN 2332-8851 2014, Vol. 1, No. 1

Department of Tourism (2012). Development Plan for Tourism Service for Tourism Free Trade Area 2012-2017, 41.

Drejer, I. (2004). Identifying innovation in surveys of services: A Schumpeterian perspective. Research Policy, 33, 551 -562.

Eisingerich, A., Rubera, G. \& Seifert, M. (2009). Managing service innovation and interorganizational relationships for firm performance: To commit of diversify? Journal of Service Research, 11(4), 344-356

Gebauer, H., Gustafsson, A. \& Witell, L. (2011). Competitive advantage though service differentiation by manufacturing companies. Journal of Business Research, 64(12), 1270-1280.

Grawe, S. J., Chen, H. \& Daugherty, P. J. (2009). The relationship between strategic orientation, service innovation, and performance. International Journal of Physical Distribution \& Logistics Management, 39(4), 282-300.

Hongqi, Z. \& Ruoyu, L. (2012). Empirical research of the relationship between customer participation, customer satisfaction and service innovation performance in China. African Journal of Business Management, 6(4), 1449-1454.

Ismail, A. \& Mamat, M. (2012). The relationship between information, process innovation and organizational performance. International Journal of Business and Social Science, 3(2), 268-274.

Jaw, C., Lo, J. Y. \& Lin, Y. H. (2010). The determinants of new service development: Service characteristics, market orientation, and actualizing innovation effort. Technovation, 30, 265-277.

Lee, G. \& Xia, W. (2006). Organizational size and IT innovation adoption: A meta-analysis. Information \& Management, 43, 975-985.

Li, Y., Zhao, Y., Tan, J. \& Liu, Y. (2008). Moderating effects of entrepreneurial orientation on market orientation-performance linkage: Evidence from Chinese small firms. Journal of Small Business Management, 46(1), 113-133.

Maatoofi, A. R. \& Tajeddini, K. (2011). Effect of Market orientation and entrepreneurial orientation on innovation. Journal of Management Research, 11(1), 20-30.

Maglio, P.P., Srinivasan, S., Kreulen, J.T. \& Spohrer, J. (2006). Service systems, service scientists, SSME, and innovation. Communications of the PCM, 49(7), 81-85.

Mattsson, J., Sundbo, J. \& Fussing-Jensen, C. (2005). Innovation systems in Tourism: The roles of attractors and scene takers. Industry and Innovation, 12(3), 375-381.

Marino, L., Strandholm, K., Steensma, H. K. \& Weaver, K. M. (2002). The moderating effect of national culture on the relationship between entrepreneurial orientation and strategic alliance portfolio extensiveness. Entrepreneurship Theory Pract, 26, 145-160. 


\section{Macrothink}

Journal of Entrepreneurship and Business Innovation ISSN 2332-8851 2014, Vol. 1, No. 1

Mavondo, F. T., Chimhanzi, J. \& Stewart, J. (2004). Learning orientation and market orientation, relationship with innovation, human resource practices and performance. European Journal of Marketing, 39(11/12), 1235-1263.

Miller, D. (1983). The correlates of entrepreneurship in three types of firms. Management Sciences, 29(7), 770-790.

Nasution, H. N., Mavondo, F. T., Matanda, M.J. \& Ndubisi, N.O. (2011). Entrepreneurship: Its relationship with market orientation and learning orientation and as antecedents to innovation and customer value. Industrial Marketing Management, 40, 336-345.

Narver, J. C. \& Slater, F. S. (1990). The effect of a market orientation on business profitability. Journal of Marketing, 54, 20-35.

Ordanini, A. \& Pasini, P. (2008). Service co-production and value co-creation: The case for a service oriented architecture (SOA). European Management Journal, 26(5), 289- 297

Roberts, P. W. \& Amit, R. (2003). The dynamics of innovative activity and competitive advantage: the case of Australian retail banking 1981 to 1995. Organization Science, 14(2), 107-122.

Scott Morton, M. (1991). The corporations of the 1990's: Information Technology and organization transformation, Sloan School of Management, Oxford University Press. New York.

Sundbo, J., Orfila-Sintes, F., Sørensen, F. (2007). The innovative behavior of Tourism firms comparative studies of Denmark and Spain. Research Policy, 36, 88-106.

Tajeddine (2010). Effect of customer orientation and entrepreneurial orientation on innovativeness: Evidence from the hotel industry in Switzerland. Tourism Management, 31, 221-231.

Thakur, R. \& Hale, D. (2012). Service innovation: A comparative study of U.S. and Indian service firms. Journal of Business Research, 88(8), 1108-1123.

Vargo, S. L., \& Lusch, R. F. (2004). Evolving to a new dominant logic for marketing. Journal of Marketing, 68(1), 1 - 17. 